\title{
RELACJE Z NIEZADOWOLONYM PACJENTEM W PODMIOCIE LECZNICZYM
}

\section{RELATIONS WITH A UNSATISFIED PATIENT AT HEALTHCARE SERVICES}

\author{
Maciej Majewski \\ DOI: https://doi.org/10.20883/ppnoz.2019.34
}

Uniwersytet Medyczny im. Karola Marcinkowskiego w Poznaniu, Katedra Prawa Medycznego, Organizacji i Zarządzania w Opiece Zdrowotnej

\begin{abstract}
STRESZCZENIE
Podmiot leczniczy, jak każda organizacja, funkcjonuje w określonym otoczeniu, w którym najważniejszym elementem są klienci-pacjenci (zarówno aktualni, jak i potencjalni). To od ich decyzji odnośnie wyboru świadczeniodawcy zależy jego sytuacja ekonomiczna (szczególnie w przypadku usług komercyjnych). Na decyzje te ma wpływ w dużej mierze ocena jakości usługi, zarówno bezpośrednia - dokonywana przez pacjenta na podstawie własnych doświadczeń, jak i pośrednia - w oparciu o opinie uzyskane od innych pacjentów. Dlatego ważne jest, aby w przypadku zgłoszenia przez pacjenta skargi czy reklamacji podmiot leczniczy reagował na nie szybko i właściwie.

Słowa kluczowe: relacje, reklamacje, marketing, jakość, marketing relacji.

\section{ABSTRACT}

Healthcare unit, like every organization, operates in a specific environment in which clients and patients (both current and potential) are the most important element. The economic situation of the institution depends on their decision regarding the choice of the service provider (especially in the case of commercial services). These decisions are influenced, to a large extent, by the quality of the service, both direct - made by the patient on the basis of their own experience, and indirect - based on the opinions obtained from other patients. Therefore, it is important that if a patient complains or complains, the medical facility responds quickly and appropriately.
\end{abstract}

Keywords: relations, complaints, marketing, quality, relationship marketing.

Dla podmiotów leczniczych szczególnie przydatną wersją marketingu jest marketing relacji, który definiowany jest jako mobilizacja personelu, prowadząca do tego, aby nabywcę (pacjenta) nie tylko uczynić współwytwórcą produktu (wartości), ale aby również związać go na trwałe z organizacją [1].

Utrzymywanie relacji z klientami i budowanie ich lojalności przynosi im wielorakie korzyści, m.in.:

1. Spadek kosztów jednostkowych każdej kolejnej transakcji - 5x taniej jest zatrzymać dotychczasowego klienta niż zdobyć nowego, a niezadowolony klient powiadamia o swym negatywnych doświadczeniach średnio 9 innych osób.

2. Ograniczenie wydatków na promocję i badania marketingowe.

3. Lepsze, tj. bardziej szczegółowe i przydatne informacje o klientach.

4. Ograniczenie ryzyka/niepewności w związku z wchodzeniem w relacje z nowymi, ale niepewnymi klientami.
5. Określenie standardów obsługi klienta.

Jeden z najistotniejszych przedstawicieli tzw. nordyckiej szkoły marketingu, E. Gummesson, wyodrębnił 30 rodzajów relacji zachodzących pomiędzy organizacją, a jej otoczeniem, które podzielił na 4 grupy [2]:

- relacje klasyczne (typowe relacje transakcyjne z udziałem bądź pominięciem pośredników - diada, triada, sieci dystrybucji),

- relacje rynkowe (najważniejsza dla marketingu relacyjnego grupa, która obejmuje oprócz klasyczne diady także relacje z ukrytymi, nierozpoznawalnymi klientami, relacje między klientami, relacje, w których nabywców traktuje się jak członków należących do organizacji),

- megarelacje (wprawdzie nie można ich nazwać rynkowymi, ale warunkują one powstanie tych ostatnich, a tworzą je relacje z mass mediami, megaalianse oraz tym podobne relacje wyodrębnione i badane przez megamarketing), 
- relacje ułomne (nanorelacje, czyli relacje karłowate, które wyróżniają się tym, że są zorientowane wewnętrznie, i które nie pojawiając się na zewnątrz przedsiębiorstwa, tworzą raczej wsparcie opisanych wcześniej relacji zewnętrznych).

E. Gummesson w swojej klasyfikacji wyróżnił m.in. relacje z niezadowolonymi nabywcami, które - mimo że są bardzo istotne dla każdej organizacji usługowej, w tym dla podmiotów leczniczych - nadal pozostają sferą zaniedbywaną przez wielu usługodawców.

\section{Marketingowa koncepcja jakości}

W marketingu relacji możemy wyróżnić różne instrumenty służące jego realizacji, w tym cykl aktywności nabywcy (Rycina 1). W modelu tym wskazano m.in., że w trakcie obsługi klienta występują tzw. momenty prawdy. Nie są to zwykłe interakcje - dotyczą tych wszystkich przypadków, gdy nabywca aktywnie i świadomie wchodzi w relacje z reprezentantem usługodawcy [3]. Pojawiają się one wprawdzie już w fazie negocjowania i nabywania, ale szczególnie dużo jest ich w fazie świadczenia i konsumowania. Zostają one finalnie "zsumowane" i decydują o tzw. kryterium prawdy, a ono z kolei w dużej mierze przekłada się na decy- zje pacjenta o wejściu w kolejny cykl. Oprócz tego po każdej z czterech faz cyklu (przedsprzedażnej, negocjowania i nabywania, świadczenia i konsumowania oraz posprzedażnej) następują utraty klienta. Utrata, która następuje po fazie świadczenia i konsumowania, jest powiązana z luką pomiędzy jakością realizacji a jakością oczekiwaną.

Jak słusznie zauważa D. Chmielewski [4], ,jJakość usług zdrowotnych podlega subiektywnej ocenie pacjentów i ich rodzin, dlatego placówki służby zdrowia muszą identyfikować i uwzględniać determinanty jakości usług i postępować tak, aby pacjent był usatysfakcjonowany". Usługa ma w oczach pacjenta odpowiednią jakość, jeśli została wykonana (przynajmniej) zgodnie z jego oczekiwaniami. Takie pojęcie jakości nazywa się jakością realizacji (postrzeganą, faktyczną). Jakość ta jest przez pacjenta zestawiana z jakością oczekiwaną, a relacje pomiędzy nimi doskonale zilustrował w swoim modelu całkowitej uświadomionej jakości Christian Grönroos (Rycina 2). Wskazał on, że jakość oczekiwana wynika z komunikacji rynkowej podmiotu (przedstawiana jest $w$ niej jakość deklaratywna) i komunikacji z ust do ust (tzw. marketing szeptany czy word-of-mouth), a jakość realizacji z jakości technicznej (co jest zrobione, tj. istota świadczenia) i jakości funkcjonalnej (jak

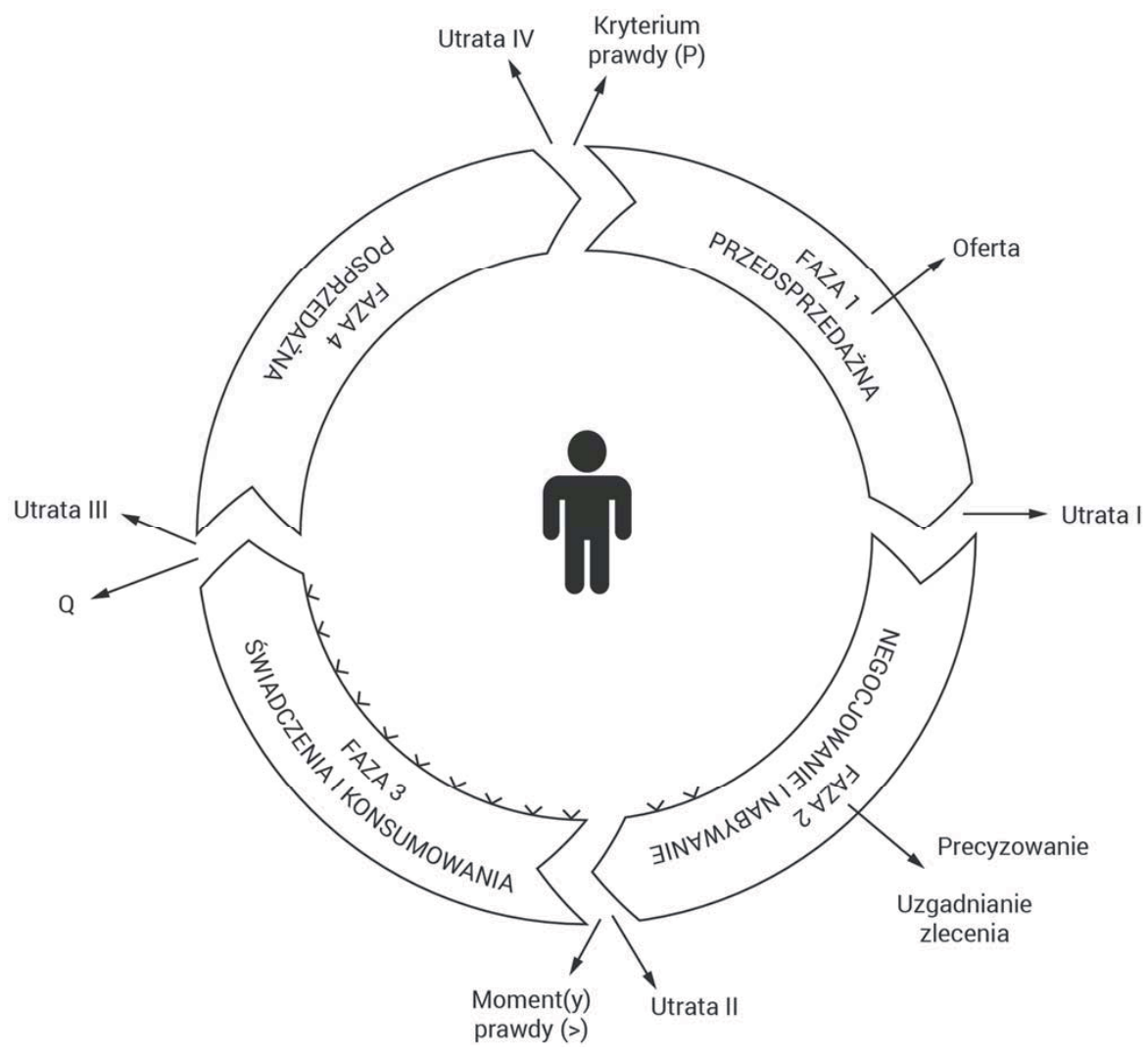

Rycina 1. Cykl aktywności nabywcy (CLAN)

Źródło: Rogoziński K. „Wprowadzenie do marketingowego zarządzania organizacją świadczącą usługi medyczne” w: Dobska M. Rogoziński K. (red) „Podstawy zarządzania zakładem opieki zdrowotnej”, PWN, Warszawa 2008, s. 235 


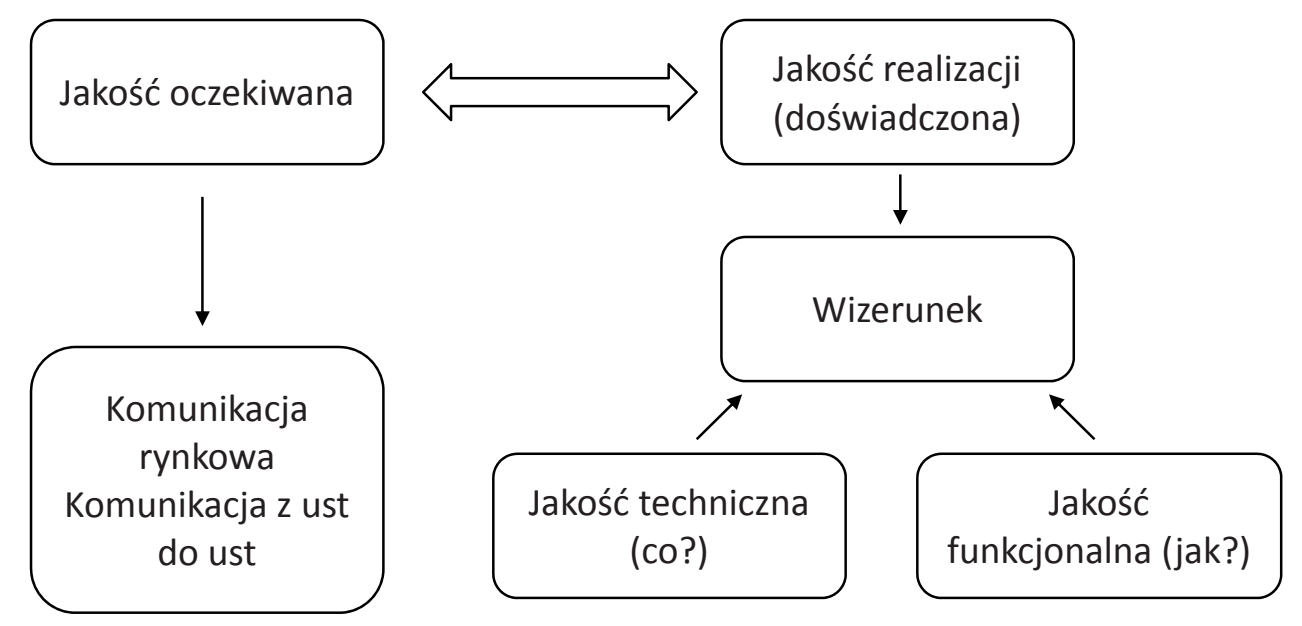

Rycina 2. Całkowita uświadomiona jakość - model C. Grönroosa

Źródło: Rogoziński K. „Marketingowa interpretacja jakości w usługach medycznych” w: Dobska M., Rogoziński K. (red) „Podstawy zarządzania zakładem opieki zdrowotnej", PWN, Warszawa 2008, s.274

ta usługa jest wykonana). W efekcie zestawiana jakości realizacji z jakością oczekiwaną możemy mieć do czynienia z jedną z trzech sytuacji:

- $Q_{\text {realizacji }}=Q_{\text {oczekivana }}$ realizacja zyskuje akceptację,

- $Q_{\text {realizacii }}<Q_{\text {oczekiwana }}$ niezadowolenie, rozczarowanie - złożenie skargi/reklamach,

- $Q_{\text {realizacji }}>Q_{\text {oczekiwana }}$ pozytywne zaskoczenie, uznanie.

V. Zeithmal, A. Parasuraman i L. Berry zidentyfikowali dziesięć kryteriów stosowanych przez konsumentów przy ocenie jakości usług [5].

- wiarygodność (credibility), co oznacza zaufanie do uczciwości usługodawcy;

- bezpieczeństwo (security) - uwolnienie od niebezpieczeństwa, ryzyka czy wątpliwości;

- dostępność (access) - przystępność i łatwość w kontaktach;

- komunikatywność/porozumiewanie się (communication) - wsłuchiwanie się w głosy klientów, bieżące ich informowanie;

- zrozumienie klienta (undestanding the custmer) - podjęcie wysitków zmierzających do poznania klienta i jego potrzeb;

- elementy materialne (tangibles) - wygląd zewnętrzny placówki, sprzęt, urządzenia, wygląd personelu;

- zdolność reagowania (responsiveness) - pragnienie udzielania pomocy klientowi i zapewnienia szybkiej obsługi;

- solidność/niezawodność (reliability) - zdolność wykonywania usług w sposób rzetelny i dokładny;

- fachowość (competence) - posiadanie wiedzy i kwalifikacji niezbędnych do świadczenia usługi;
- uprzejmość (courtesy) - przyjazna postawa wobec klienta, szacunek.

Dokonując analizy zjawiska satysfakcji V. Zeithaml i M. Bittner wyodrębnili trzy typy oczekiwań dotyczących jakości usługi [6]:

- usługa pożądana - poziom usługi, który klient ma nadzieję otrzymać, kompozycja tego co "powinno być" z tym, co "może być";

- usługa adekwatna - poziom reprezentujący minimalne akceptowanie usługi, wynikający z przekonania, że usługa pożądana nie zawsze jest możliwa;

- usługa przewidywana (prorokowana) - poziom, który klient postrzega jako prawdopodobny do uzyskania, skorygowany o obiektywną kalkulacje.

Jeśli wynik porównania jakości oczekiwanej z jakością realizacji wypadnie niekorzystnie, mogą nastąpić dwa możliwe warianty. Może dojść do utraty III (zgodnie ze schematem przedstawionym na rycina 1), a wtedy organizacja nie ma żadnych szans na podjęcie działań dających szansę na naprawę nadszarpniętego wizerunku. Pacjent może też - pomimo niezadowolenia - przejść do fazy posprzedażnej, w której działania usługodawcy obejmują m.in. obsługę reklamacji czy formułowanie wniosków i zaleceń dotyczących doskonalenia obsługi klienta.

Za względu na zakres tematyczny, skargi i reklamacje mogą być zakwalifikowane do jednej z czterech grup:

- związane bezpośrednio ze świadczeniem usługi medycznej - dostarczenie rdzennej usługi o nieodpowiedniej jakości lub niedopasowanej do potrzeb zdrowotnych pacjenta;

- związane z zachowaniem personelu medycznego w trakcie świadczenia usługi; 
- $\quad$ związane z zachowaniem personelu niemedycznego (głównie rejestracja/recepcja);

- związane z procesami obsługi pacjenta i organizacji pracy jednostki.

Pierwsza z grup związana jest z rdzeniem usługi medycznej, czyli jej częścią, która jest bardzo zbliżona we wszystkich jednostkach medycznych. Z kolei pozostałe grupy - zwłaszcza ostatnia - związane są z tzw. otoczką marketingową usługi, czyli tym, co wyróżnia placówkę na tle innych podmiotów i stanowi jej przewagę konkurencyjną (tzw. USP czyli tzw. unique sales proposition).

\section{Reklamacja jako niezgodność}

Wiele podmiotów leczniczych posiada wdrożoną normę PN -EN ISO 9001:2015. W aktualnej wersji tej normy stawia się duży nacisk na podejście oparte na ryzyku, PDCA (plan, do, check, act, czyli planuj, wykonaj, sprawdź, działaj) i podejście procesowe. Podejście oparte na ryzyku ściśle wiąże się z reklamacjami i skargami, które w normie ISO należy utożsamiać z niezgodnością. Ma to wyraz w szczególności w następujących elementach normy:

- Rozdział 8. „Działania operacyjne” - od organizacji wymaga się, aby zarządzała swoimi procesami operacyjnymi oraz wdrożyła działania odnoszące się do ryzyka. W rozdziale tym znajduje się punkt 8.7 „Nadzór nad niezgodnymi wyjściami” (odpowiadający punktowi 8.3 „Nadzór nad wyrobem niezgodnym" w wersji normy z 2008 r.), w którym na organizację nakłada się obowiązek m.in. prowadzenia zapisów niezgodności i podjętych działań.

- Rozdział 10. „Doskonalenie” - od organizacji wymaga się, aby korygowała, zapobiegała lub ograniczała niepożądane skutki i doskonaliła system zarządzania jakością oraz aktualizowała ryzyka i szanse. W znajdującym się w tym rozdziale punkcie 10.2. "Niezgodność i działania korygujące” wymienia się m.in. dowody charakteru niezgodności i wszelkich podjętych w ich następstwie działań oraz wyniki każdego podjętego działania korygującego, a w punkcie 10.3. mowa jest o ciągłym doskonaleniu, czyli też działaniach zapobiegawczych.

Oznacza to, że organizacje, mając sformalizowany system zarządzania jakością, muszą traktować obsługę reklamacji pacjentów nie tylko jako element kształtowania wizerunku, ale także ważny aspekt procesów zarządzania ryzykiem.

\section{Rola obsługi reklamacji}

Rola relacji z niezadowolonym klientem wynika między innymi z faktu, że - jak wspomniano wcześniej - dużo taniej jest utrzymać dotychczasowego klienta/pacjenta (a także rozszerzać wolumen sprzedawanych mu usług) niż pozyskać nowego. Dodatkowo niezadowolony pacjent może mieć negatywny wpływ na wizerunek organizacji, opowiadając o nieodpowiednim potraktowaniu w danym podmiocie leczniczym swojej rodzinie i znajomym a także - za pośrednictwem Internetu - szerokiemu gronu potencjalnych pacjentów (jak również powszechnie wiadomo, negatywnymi opiniami dzielimy się znacznie chętniej niż pozytywnymi). Od eksplozji popularnośc mediów społecznościowych, pacjenci bardzo chętnie opisują swoje negatywne doświadczenia z placówkami medycznymi na ich profilach na Facebooku czy wizytówkach wwyszukiwarce Google, awprzypadku konkretnego lekarzaw portalach typu znany lekarz czy ranking lekarzy. Bardzo duży wpływ na innych potencjalnych pacjentów mają też informacje przekazywane na różnych forach czy grupach zrzeszających osoby z tym samym problemem zdrowotnym. Zasięg oddziaływania tego typu rekomendacji jest jeszcze większy, a wiarygodność porównywalna z opiniami przekazywanymi bezpośrednio [7]. Ze względu na wzrost popularności poszukiwania w Internecie w fazie przedsprzedażnej CLAN - pod wypływem bodźca (stimulus) - wszelkich opinii i rekomendacji o usłudze, powstał termin „zero moment of truth" (ZMOT - zerowy moment prawdy). Przed jego wprowadzeniem, w procesie zakupowym wyróżniano pierwszy moment prawdy (FMTO), który następował dopiero $w$ fazie nabywania i negocjowania oraz drugi moment prawdy (SMTO) - w fazie świadczenia, gdy klient korzystał już z produktu/usługi.

W przypadku pacjenta, w odczuciu którego organizacja i jej personel nie zachował się w sposób, jakiego oczekiwał sprawność i profesjonalizm reakcji na jego skargę/reklamację może przełożyć się w znacznym stopniu na jego dalsze postępowanie. Może skutkować zarówno kolejnymi negatywnymi opiniami o placówce przekazywanymi dalej („Nie dosyć, że mnie źle obsłużyli, to jeszcze źle mnie potraktowali, gdy złożyłem skargę/W ogóle nie odpowiedzieli na złożoną skargę"), jak i wystąpieniem z formalnymi roszczeniami w stosunku do podmiotu. Niezwykle istotny jest szybki kontakt przedstawiciela jednostki z pacjentem, aby wiedział on, że jego skarga nie trafiła w próżnię i - szczególnie w przypadku „skargi” zamieszczonej w Internecie - nie atakował placówki za brak reakcji. Poza tym taki kontakt jest okazją do zebrania dodatkowych informacji, które pomogą w wyjaśnieniu zaistniałej sytuacji.

Ważne jest również, aby przy rozpatrywaniu skargi/reklamacji odejść od podejścia „pacjent na pewno nie ma racji i jest roszczeniowy", z którym nadal możemy spotkać się w placówkach medycznych. A jeśli popełniliśmy błąd, to 
traktujmy pacjenta partnersko: prowadźmy z nim otwartą komunikację, przyznajmy się do ewentualnego błędu i pokażmy, jakie podjęliśmy działania korygujące, by sytuacja nie powtórzyła się w przyszłości (uczenie się na błędach jest w końcu jedną z cech organizacji uczącej się).

Dobrą praktyką przyjętą w wielu placówkach medycznych jest - w przypadku uznania skargi za zasadną - oprócz przeproszenia pacjenta zaoferowanie bezpłatnie kolejnej usługi. Daje to szansę następnej interakcji pomiędzy pacjentem a organizacją, co jest okazją na wykazanie, że sytuacja będąca przedmiotem skargi czy reklamacji była wyjątkiem od reguły, a działania naprawcze są rzeczywiście skuteczne (a nie wymyślone czy pozorowane). Właściwe wykorzystanie tej szansy pozwala na pozostawienie dobrego wrażenia w pamięci pacjenta, a nawet jeszcze trwalsze związanie go z naszą placówką.

\section{Podsumowanie}

Dla podmiotu leczniczego „klient i jego opinia powinny być w centrum uwagi, pomimo że jego poglądy nie zawsze muszą być zbieżne z opiniami ekspertów w danej dziedzinie. $Z$ tego względu cały proces zapewnienia jakości powinien być nierozłącznie związany z badaniem i rozumieniem potrzeb klienta" [8]. Dlatego kierownictwo każdej placówki - mającej wdrożony system zarządzania jakością czy też nie - powinno wprowadzić u siebie sformalizowany proces obsługi niezadowolonego pacjenta. Korzyści $z$ tego płynące to m.in.:

- $\quad$ skrócenie czasu obsługi skargi czy reklamacji warto przy tym określić wskaźnik SLA (Service Level Agreement), czyli wskaźnik realizacji usługi/ świadczenia w określonym terminie np. 90\% skarg i reklamacji rozpatrzonych $w$ terminie do 7 dni, a wszystkie w terminie 14 dni od daty wpływu;

- ujednolicenie postępowania całego personelu w tym zakresie (w przypadku podmiotów leczniczych posiadających wdrożoną normę ISO 9001 przeważnie jest przygotowana instrukcja obsługi skargi i reklamacji);

- pewność zebrania wszystkich koniecznych informacji odnośnie zaistniałej niepożądanej sytuacji;
- zdiagnozowanie wszystkich rzeczywistych przyczyn skargi/reklamacji, dzięki czemu podjęte działania korygujące będą skuteczne;

- ograniczenie kosztów (finansowych i wizerunkowych) związanych ze skargą/reklamacją.

\section{Oświadczenia}

Oświadczenie dotyczące konfliktu interesów

Autorzy deklarują brak konfliktu interesów.

\section{Źródła finansowania}

Autorzy deklarują brak źródeł finansowania.

\section{Piśmiennictwo}

1. Rogoziński K. Wprowadzenie do marketingowego zarządzania organizacją świadczącą usługi medyczne w: Dobska M Rogoziński K (red.). Podstawy zarządzania zakładem opieki zdrowotnej, PWN, Warszawa 2008, s. 229.

2. Dobska M, Dobski P. Zarządzanie jakością w podmiotach leczniczych, Wolters Kluwer, Warszawa 2012, s. 106-107.

3. Rogoziński K. Wprowadzenie do marketingowego zarządzania organizacją świadczącą usługi medyczne w: Dobska M Rogoziński K (red.). Podstawy zarządzania zakładem opieki zdrowotnej, PWN, Warszawa 2008, s. 238.

4. Nowatorska-Romaniuk B. Marketing usług zdrowotnych. Koncepcja i stosowanie, Wolters Kluwer, Warszawa 2008, s. 64.

5. Rogoziński K. Marketingowa interpretacja jakości w usługach medycznych w: Dobska M, Rogoziński K (red.). Podstawy zarządzania zakładem opieki zdrowotnej, PWN, Warszawa 2008, s. 273-274.

6. Rudawska I. Opieka zdrowotna. Aspekty rynkowe i marketingowe, PWN, Warszawa 2007, s. 152-153.

7. Krot K. Jakość i marketing usług zdrowotnych, Wolters Kluwer, Warszawa 2008, s. 111.

8. Dobska M, Dobski P. Zarządzanie jakością w podmiotach leczniczych, Wolters Kluwer, Warszawa 2012, s. 13.

Zaakceptowano do edycji: 20.08.19 Zaakceptowano do publikacji: 26.09.19

\section{Adres do korespondencji:}

Maciej Majewski

Uniwersytet Medyczny im. K. Marcinkowskiego w Poznaniu

Zakład Organizacji i Zarządzania w Opiece Zdrowotnej

ul. Przybyszewskiego 39

60-356 Poznań 